\title{
Schopenhauer's Demythologization of Christian Asceticism
}

Robert A. Gonzales

Holy Cross Church

In the hiscory of Western thought there has been no greater exponent of philosophical pessimism than Arthur Schopenhauer, the nineteenth century post-Kantian. Though Mandelbaum, an authority on nineteenth century thought, denies that Schopenhauer's Weltanschauung contains any particularly 'novel insight', his contribution to Western thought is minimized if one sees him merely as a systematizer of "diverse strands of thought into a single encompassing system." " Neither should conjectures of Schopenhauer's reputed atheism blind one from determining more closely what constitutes his atheism. And, a fortiori, such bias should not blind one from considering what schopenhauer has to say about Christianity.

The objective of this article is to go beyond this scotosis and analyze the relationship between Schopenhauer's philosophy of the denial of the will-tolive and Christian asceticism. Following the groundwork already laid by Harry J. Ausmus ${ }^{2}$, this inquiry has a twofold purpose: in the first place, it aims to establish why Schopenhauer's philosophy of the denial of the will-to-live can be seen as an attempt to demythologize Christian asceticism; and secondly, it aims to determine whether that supposed demythologization is interpretative or destructive.

\section{I}

But, before this inquiry can begin, the debris which lies on our path must first be cleared. I refer here to the intellectual bias that traditionally has prevailed concerning Schopenhauer's 'atheistic' stance. The following are some examples: Hollingdale writes that Schopenhauer's philosophy is atheistic and that "there is no God in Schopenhauer's world as will and idea." " Russell, though refraining from declaring categorically that schopenhauer is an atheist, writes that Schopenhauer "dislikes Christianity, preferring the religions of India, both Hinduism and Buddhism." " 
Copieston suggests that Schopenhauer's philosophy of salvation is more Buddhist than Christian." And Gardiner contends that a world view such as Schopenhauer's without any 'benevolent deity' would be totally lacking in a morally acceptable design."

Upon scrutiny, however, the aforementioned opinions are at least open to question. For, in the first place, Schopenhauer himself appears to leave room for the existence of God in his writings. Or, at least, he does not deny the existence of God outright:

. . the impossibility to prove the existence of God does not in the least call into question that existence itself, for it stands on much firmerground (viel sicherem Boden). Indeed, it is a matter of revelation (Es ist ja sache der Offenbarung), and of course this is the more certain, as it was vouchasafed solely and exclusively to those who for that reason are called the chosen race.'

In the Christian religion the existence of God is an established fact (eine ausgemachte Sache) beyond and above all investigation. This is as it shoule be; for here it properly belongs and is established by revelation (durch offenbarung begrundet). I therefore regard it as a mistake on the part of the rationalists, when they attempt in their dogmas to demonstrate the existence of God otherwise than from the scripture."

Hence, there is doubt as to whether schopenhauer in fact does deny that God exists. For while it may be argued that he does not take God as seriously real in his Weltanschauung, this is a far cry from calmly asserting His total absence.

secondly, though schopenhauer did admire the sapiential writings of the East, and notwithstanding the fact that his philosophy of salvation is akin to the Buddhist doctrine of the four truths, ${ }^{\circ}$ this certainly is not to say that he 'dislikes' Christianity as Russell maintains. Granted, he does grant to Buddhism a preeminence over other religions, but he also states that his philosophizing has not been under its influence. "1 Schopenhauer does in fact leave room for 'genuine Christianity' which, as he interprets it, propounds ascetical self-denial upon recognition of the inherent evil of existence--especially in lieu of the hope for a 'better world'.12

It can be argued that Schopenhauer is as interested in Christianity as he is in Buddhism because both contain the theme of asceticism and quietism which "is identical with that of all metaphysics and ethics." 3 The ascetical character and tendency, which is described in his philosophy as denial of the will-to- 
live, is not only characteristic of the religions of the East with their suppression of desire, but in "gemuine and original Christianity, as it was developed in the writings of the Church Fathers from the kernel of the New Testament. "1" Consequently, his 'dislike' of Christianity has to be considered against the backdrop of of his admiration for the ethical tendencies of both Christianity and Buddhism. For as Schopenhauer wites: "In truth it is not Judaism with its

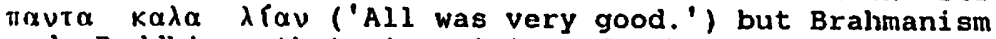
and Buddhism that in spirit and ethical tendency are akin to Christianity." 1 s

Thirdly, even Gardiner's contention that Schopenhauer's Weltanschauung lacks a morally acceptable design is open to dispute. For though it can be argued once again that God is not really real in Schopenhauer's world picture, he does not state that the world is devoid of a morally acceptable design. In parerga and Paralipomena, the work of Schopenhauer's later years, he states: "That the world has only a physical and not a moral significance is a fundamental error, one that is the greatest and most pernicious, a real perversity of the mind. At bottom, it is also that which faith has personified as antichrist."16 Suffering, moreover, can have meaning. In fact, according to Schopenhauer, it can be considered metaphysically to be a 'blessing'.17

Having at least wounded three of the cows fed by philosophical prejudice and bias, the stage is now set for an examination of the relationship between Schopenhauer's doctrine of the denial of the will-to-live and the ethical aspect of Christian asceticism. After all, Schopenhauer in Parerga and Paralipomena claims that his teaching can "be called Christian philosophy proper, paradoxical as this may seem to those who do not go to the root of the matter, but stick merely to the surface." 1 :

At this juncture, therefore, I propose to 'go to the root of the matter' and take up the gauntlet Schopenhauer offers. Why can Schopenhauer's philosophy of the denial of the will-to-live be considered a demythologization of Christian asceticism?

\section{I I}

Prior to answering why Schopenhauer's philosophy of the denial of the will-to-live can be considered a demythologization of Christian asceticism, it shall be necessary to analyze briefly schopenhauer's distinction between representation and will. For it is precisely here where the meaning of justice, charity and selfdenial can be exhibited." Without a general understanding of Schopenhauer's phenomena-noumena distinction, the significance of his claims about christian spirituality cannot adequately be grasped. 
In the very first sentence of The World as Will and Representation Schopenhauer makes an important claim: "The world is my representation (Die Welt ist meine Vorstellung): this is a truth valid with reference to every living and knowing being, although man alone can bring it into reflective, abstractive consciousness. "zo What does this mean in general lines?

In the first place, it signifies that all knowledge is basically representational 21 -which is to say that we can never know a given object $x$ directly--or initself; a subject-object relationship is necessarily presupposed. Or, to quote Schopenhauer, "between things and us there always stands the intellect." 22 Everything that exists independent from myself--and which I know--is "inevitably associated with this being-conditioned by the subject, and exists only for the subject."23 Thus, it is $I$ who impose the categories of my understanding (Verstand) upon the sensations which I receive from that which exists independently from them in the 'external world'. The a priori category of the understanding with its forms of causality, time and space "creates and produces the objective external world of a few sensations in the organs of sense." $2 "$

But the representational knowledge of the world leaves much to be desired. The intellect and its a priori categories are not designed to give us knowledge of the 'true' nature of things. According to Schopenhauer. representational knowledge of things outside us "can never be identical with the being-in-itself of the thing outside me". "s The world, schopenhauer asserts, is much more than the end result of this type of knowledge that cannot penetrate the deep recesses of the self in which the 'ultimate secrets' lie.26

Herein the influence of Kant is visible. Kant likewise emphasized the phenomena-noumena distinction. However, he denied the possibility of knowing things in themselves.27 Metaphysical knowledge of the initselfness of reality is impossible in the Kantian Weltanchauung.

Admitting with Kant that representational knowledge cannot pierce the riddle of existence, Schopenhauer differs from him in that he opened the possibility for another type of knowledge which comes from within the recesses of the consciousness"--that in turn manifests itself in acts of desiring, striving, wishing, longing, etc. 29 Unlike representational knowledge which is mediated and more indirect, this type of knowledge gives one a direct intuition of what he is in himself. It is the type of knowledge by which one is aware of pain and pleasure. Schopenlauer calls this type of intuitional knowledge will."

Schopenhauer continues by asserting that it is totally different than representational knowledge which is mediated through the category of the understanding. 
He writes that it is "neither a perception (for all perception is spatial), nor is it empty, on the contrary. it is more than any other knowledge... it is not a priori, like merely formal knowledge, but entirely a posteriori. hence we are unable to anticipate it in the particular."

Since this knowledge is so different from representational knowledge, Schopenhater's next logical step is understandable: namely, that the laws of phenomenal knowledge do not apply to it except for the form of time. ${ }^{2}$ For the will as such is known only through particular acts which are known a posteriori. But what is interesting to note is that Schopenhauer asserts that this type of knowledge is the key to understanding the riddle to both man and universe. For if one recalls, according to Schopenhauer, the secrets to the world lie within man himself. It is this different type of knowledge which reveals what reality is initself."3

Schopenhauer's illicit logical step, therefore, is clearly visible. For the immediate and intimate knowledge one has of himself as a willing and striving being is transferable to the whole of reality. Even the forces of nature, according to schopenhauer, are identical with the will in ourselves." Thus, the word 'will' describes that force within ourselves and everything in the world which is "the sole kernel of every phenomenon (der alleinige Kern jeder Erscheinung). "3s

The inner knowledge which we supposedly have of ourselves, therefore, has been hypostasized into a force and applied to the whole of phenomena. "Considered purely in itself", Schopenhauer writes, "I the will is devoid of knowledge and is only a blind, irresistible urge (nur ein blinder, unaufhaltsamer Drang), as we see it appear in inorganic and vegetable nature and their laws and also in the vegetative part of our life." 36 Its nature is always to strive without final satisfaction:

At all grades of its phenomenon from the lowest to the highest, the will dispenses entirely without an ultimate aim and object. It always strives, because striving is its sole nature, to which no attained goal can put to an end. Such striving is therefore incapable of final satisfaction; it can be checked only by hindrance, but in itself goes on forever."?

Schopenhauer's illogical jump is akin to an evolutionary process which occurred in the Hindu religion, to which Thomas Berry alludes." At a specific period in the history of Hindu thought, the unity between Atman and Brahman was perceived. Atman and Brahman, as the supports of Being. botll came to represent the supreme reality as experienced respectively in the sub- 
jective and objective orders. To put it simply, the difference between the two words, for all practical purposes, collapsed. For Atman was identified with Brahman.

In Schopenhauer's philosophy it is the same subjective will that is present in the whole of reality. As such, therefore, it appears that it is not the individual per se who wills to live--who is the conglomeration of concrete willing and needing--that is foremost in Schopenhauer's philosophy. For as Schopenhauer writes: "what craves so impetuously for existence is merely indirectly the individual; directly and properly speaking, it is the will-to-live in general, which is one and the saine in all." "Hence, will as thing-in-itself is identically present in every phenomenon. It is only with increasing consciousness as manifested in the higher levels of the will's objectification that suffering and the will's horror increases. And in man with his faculty of Vernunft the suffering is especially tragic." 0

Why the suffering? Why the horror? Because the basis of all willing is "need, lack, and hence pain","1 suffering is essential to life. For the will's striving is insatiable; its nature is to perpetually strive." 2 For nothing can possibly satiate the will. As such a Summum Bonum is a contradiction in the Schopenhauerian Weitanschauung. 'Good' in schopenhauer's eyes is a relative concept related only to the desiring will. The so-called summum Bonum would be that which could halt the striving and longing of the will. But such a reality is impossible given Schopenhauer's presuppositions."

In the Schopenhauerian Weltanschauung it is evil which is positive, good is negative. For willing, in which pain and need are intertwined, is what is primary. The 'good' which is defined only in reference to the desiring will, is at best illusory; for the will can never be satiated.

Now, since the will is the primordial force of reality, man as a phenomenon in which the will objectifies itself, "is concrete willing and needing through and through; he is a concretion of a thousand wants and needs." "The faculty of Vernunft, moreover, increases the motives of the will. For man alone transcends the eternal present. Both the future and the past are his concerns.

His consclousness, in short, is filled with willing. As such, knowledge remains at the service of the will--which points towards objects that would seemingly alleviate the pain of existence." But the flux of life rolls irresistibly on. Despite the ephemeral nature of existence, man blinds himself to this unhappy 
fact, acting as if it were not. For as Schopenhauer writes: "This is the life of almost all men; they will, they know what they will and they strive after this with enough success to protect them from despair. and enough failure to preserve them from boredom and its consequences." "s"

But though suffering and death everywhere prevail, he alone consciously revolts against his fate. The nothingness from which he comes haunts him. He seeks an answer as he marches irresistibly toward the abyss of non-existence whence he came. His heart ripped apart by the decree of the Eates, he none the less affirms the will-to-live (der Wille zum Leben)" convinced that nature's verdict cannot be right. Yet, in the final analysis, the rocks of death loom in the horizon and destroy the phenomenon whose expression he is.

Moreover, because each man is aware of himself directly and of others only indirectly, " egoism characterizes his very self--the core of his being. Man is quite naturally more prone to achieve the objects of his own willing than those of another. He is much more apt to define the 'good' in reference to his own will--and all too often at the expense of another. He is, as Schopenhauer states, "ready to annihilate the world, in order to maintain his very self, that drop in the ocean. "."s

Man, therefore, is in the center of a world stage torn apart by a fierce struggle in which individual entities strive to affirm their own particular wills." In him the ferocity of the struggle is most intense. For unlike animals, for example, who use force to attain their individual ends, man can place cunning at his will's service. As Schopenhauer observes: "I, as the wrongdoer, compel the other individual to serve my will instead of his."sl In short, man's nature cannot be satisfied by the mere affirmation of his own needs. He advances beyond the affirmation of his bodily needs. And because there is to be found in every human being "a store - . . of hatred, anger, envy, rancour, and malice" 52 he even goes to the extreme of basing his happiness on the miseries of others. As Schopenhauer: writes, "it is the will-to-live las expressed by the individuall which, more and more embittered by the constant suffering of existence, seeks to lighten its own pain and distress by inflicting them on others."s,

Is there any hope for the human condition then? How can man recognize the oneness of reality if his knowledge of the other is representational and indirect? How can he possibly realize that by inflicting suffering upon the other he thereby fights against that which he himself is--namely an instance of the will's objectification? Shackled to the principle of sufficient reason," affirmation of the will (die Bejahung des Willens) appears inevitable."s 
But Schopenhauer asserts that man is a special phenomenon in that he can transcend his condition. Only in him can freedom (independence from the principle of sufficient reason which, as such, belongs only to the will as thing-in-itself) 'possibly' appear in the phenomenal expression of himself as an intellectual being."s

In this regard Schopenhauer is like Kant who, in the Critique of Pure Reason, established the possibility of freedom and necessity existing together. 17 However, unlike Kant, Schopenhauer does not believe that the concept of freedom arises from "an inference either from the Speculative Idea of an unconditioned cause, or from the fact that the categorical imperative presupposes it." " Rather, Schopenhauer stresses that the concept of freedom arises from the immediate knowledge of one's will in the human consciousness (") - unmittelbare Erkenntniss des eigenen Willens $\dot{-}-\dot{-}$ im menschlichen Bewusstseyn. . ")."3 The probiem with man is that he is also a phenomenon and conseguently governed by the principle of sufficient reason.

Because the will in ordinary consciousness is confused with the phenomenon, what belongs to the will as thing-in-itself (freedom) is attributed to the phenomenon. Therein arises what Schopenhauer calls the "delusion of the individual's unconditioned freedom." Ereedom, argues Schopenhauer, is tied with the notion of responsibility (die Verantwortlichkeit). Because of "the wholly clear and certain feeling of the responsibility for what we do, of the accountability for our actions", the objective possibility for having acted otherwise exists."

Servitude to the will may be transcended insofar as the consciousness of freedom which everyone has, presents the objective possibility for non-affirmation of the will. Man, according to Schopenhauer, can escape the vicious circle in which he seemingly is ensnared. He can transcend the suffering and ennui about him. He can pierce the veil of Maya which veils the oneness of reality.

However, Schopenhauer's reflections on the possibility of transcending the will are watered down by his stressing that the character of man is like the natural forces in that it is original, unchangeable and inexplicable. ${ }^{62}$ He states clearly:

- . the difference of characters is innate and ineradicable. The wicked man is born with wickedness as much as the serpent is with its poisonous fangs and glands; and he is as little able to change his character as the serpent its fangs. 63

It would appear then that character reform is possible only in some. For those inexplicably cursed with 
irieformable characters, transcending the will, it would seem, would not be a real possibility. Schopenhauer's ethic of liberation or salvation is geared for the few. For in Schopenhauer's Weltanschauung most men are doomed to perpetually undergo the throes of suffering and ennui because of the constancy of their characters.

Because of the difficulties hitherto alluded, it is more accurate to state that for schopenhauer some men are capable of abandoning knowledge of individual entities as such. Some are capable of transcending servitude to the principle of sufficient reason which entails two steps: aesthetic contemplation and denial of the will-to-live which in turn can lead to a rigorous asceticism--once again on the part of some.

Both steps concern a different type of knowledge whereby the individual can transcend the representational knowledge he has of particular entities as multiplied by the principle of sufficient reason. In the first stage this type of knowledge is called aesthetic contemplation--be it the appreciation of a landscape, music or a piece of art. Such contemplation is different from knowledge of particular things insofar as the perceiver becomes the pure subject of knowledge, knowing only the Ideas (in which the will immediately objectifies itself)--and not their particular instances."

Individuality as such, therefore, is forgotten or laid aside. The motives which induce the will to operate are stilled. The perceiver continues to exist, of course, but only as "the pure subject, as the clear mirror of the object, so that it is as though the object alone existed without anyone to perceive it."ls According to Schopenhauer, in this plateau of transcendence, the perceiver can no longer be separated from the object of his perception. For the entire consciousness is filled by this strange perception:

When . . an external cause or inward disposition suddenly raises us out of the endless stream of willing, and snatches knowledge from the thraldom of the will, the attention is now no longer directed to the motives of willing, but comprehends things free from their relation to the will. Thus it considers things without interest, without subjectivity, purely objectively - . for that moment we are delivered from the miserable pressure of the will. We celebrate the sabbath of the penal servitude of willing; the wheel of Ixion stands still.66 
Hence, the perceived individual thing is raised to "the idea of its species, and the knowing individual to the pure state of will-less knowing, and now the two, as such, no longer stand in the stream of time of ali other relations."' Tragically, however, this plateau can be scaled only with great difficulty. And, being at best a fleeting phenomenon, aesthetic contemplation can bring no lasting peace from the ever-present will. Despite the fact that 1 ife's inner nature is recognizable upon reflection, the individual persists in satiating the metaphysical will. Shackled to the principle of sufficient reason, he affirms the will-to-live seeing only the diversity of phenomena. And because man wills with knowledge, guilt gnaws at his conscience."

But, for the few enlightened, a more permanent liberation can be attained--which need not follow from the first stage of liberation. This higher type of knowledge, according to Schopenhauer, can actually silence the will's fury. For as he writes. "the denial of the will-to-live (die Verneinung des Willens zum Leben) shows itself when willing ends with that knowledge, since the peculiar phenomena known then no longer act as motives of willing, but the whole knowledge of the inner nature of the world that mirrors the will, knowledge that has grown up through apprehension of the Ideas, becomes the quieter of the will (Quietiv des Willens), and thus the will freely abolishes itseif (der Wille frei sich selbst aufhebt). "G

It is the enlightened Individual who can glimpse the noumenon which objectifies itself in the totality of phenomena. It is he who can recognize the same will constantly striving in each phenomenon. Thus, he will no longer see the difference between the one who inflicts suffering and the one doomed to endure it. Eor as Schopenhauer states, "tormentor and tormented are one. "I0

But what is it that wills? Is it the universal will that craves and desires? Or is it the individual? Does not the individual have almost a secondary role? For Schopenhauer implies that it is the will which affirms itself and likewise denies itself. But if the will is blind, how can affirmation or denial be predicated of it? For if the will is blind and irresistible. how can it have power to turn on itself and deny itself? And supposing that it did have the power to do so, why cannot this same will turn on itself in the lower grades of its manifestation?

Notwithstanding the difficulties these questions put forth, it is no suprise that Schopenhauer returns to the conscious and knowing subject (who, at times, appears secondary) when discussing both the affirmation and denial of the will. Accordingly, it is to man with his faculties of Verstand and Vernunft that velle (willing) and nolle (not-willing) concern. 
The second plateau of the denial of the will-tolive, then, is not the absorption of the perceiver into the object of perception--a process which is, at best, temporary and fleeting. Rather, in this phase of liberation, the individual undergoes a gradual transformation insofar as he increasingly denies what he once so vehemently willed. Coming to a better understanding of existence, he shrinks in horror at the fact that that which he wills so fiercely is what he is at the core of his being--the very reality which adds to his sufferings, namely the will. Thus, the more enlightened the person becomes, the more he will begin to deny his very self which is the highest expression of the metaphysical will."'

But at no point does the conscious being annihilate his proper selfhood. Eor, as Schopenhauer writes, the subject of velle and nolle "is one and the same and consequently, as such, is not annihilated by one act or the other."iz Thus, denial of the will-to-live does not signify the total annihilation of a conscious subject (die Vernichtung einer Substanz). Rather, as the older schopenhauer writes in Parerga and Paralipomena, it signifies "the mere act of not-wiling; that which hitherto willed no longer wills (das selbe was bigher gewollt hat, will nicht melir)

suicide, it is interesting to note, is not a form of the denial of the will-to-live. The reputation of Schopenhauer being the philosopher of suicide is a gross fabrication. For as he writes:

Far from being denial of the will, suicide is the phenomenon of the will's strong affirmation (ein Phänomen starker Bejahung des Willens). For denial has its essential nature in the fact that the pleasures of life not its sorrows, are shunned. The suicide wills life (Der Selbstmörder will das Leben), and is dissatisfied merely with the conditions on which it has come to him. Therefore, he gives up by no means the will to live, since he destroys the individual phenomenon."

The will as the noumenal reality is not affected by the act of suicide--and this despite the destruction of the individual phenomenon. ${ }^{35}$ The will cannot be denied through force. Rather, the path toward salvation lies in the embrace of suffering through painstaking denial of the will-to-live. Schopenhauer's own words claify the above:

The will can't be abolished by anything except knowledge. Therefore the only path to salvation is that the will should appear freely and without hindrance, in order that it" can recognize or know its own inner nature." 
The second stage of denial of the will-to-live is gradual and can be reached only with great difficulty. At this point in the discussion one may well wonder why Schopenhauer's view of reality has been given so much attention in light of the article's purpose. However, as the argumentation progresses, it will become evident that the meaning of compassion, love, and asceticism is connected with the distinction schopenhauer draws between the world as representation and will. According to the indirect knowledge given through representation, entities independent of the perceiver seem totally different from the perceiver. One's consciousness stubbornly asserts the aforementioned fact. But the inner, intuitive knowledge we have of ourselves suggests that that which is independent of the perceiver is what the perceiver is--namely will. Thus Gardiner is right in stating that "the inner import and meaning of justice, of charity, and also--ultimately-of self-denial, can be satisfactorily exhibited through [Schopenhauer's] original distinction between appearance and reality in terms of idea and will." 7

In his essay on the Basis of Morality Schopenhauer distinguishes between what he calls the principle of ethics' (das Princip der Ethik--which is nothing more than the quintessential statement of the line of conduct demanded by an ethical system) and the 'foundation of ethics' (das Eundament der Ethik) which explains why one ought to do this or that. In a word, since Schopenhauer considers "neminem laede, imo omnes quantum potes juva" (Injure no one; on the contrary, help everyone as much as you can.) ${ }^{\text {is }}$ to be the ethical principle of most systems, he aims to discover its ground.

It is interesting to note that Schopenhauer never denied that man was capable of lawful or just actions. He did, however, question whether most men were capable of disinterested actions. The following illustrates this:

We should be . . . childishly mistaken if we thought that all the just and lawful acts of mankind had a moral origin.. . In reality, universal honesty and uprightness, as practiced in human intercourse and affirmed in the most unshaken maxims rests mainly on two external necessities: first, on the order of the law whereby everybody's rights are protected by public authority, and secondly, on the recognized necessity of a good name or civil honor for making one's way in the world."

Even religious faith is rarely so firm as to result in a disinterested morality. Selfishness too often is 
disguised under so-called 'good acts'. For example, one can treat his neighbor well for fear of what may happen in an after life. Schopenhauer does not deny outright the existence of a genuine morality or of individuals who may practice it. But he does suggest that "we moderate our expectations of the moral tendency in man and consequently of the natural foundation of ethics." 1

Thus, since Schopenhauer believes that egoism and moral wort) mutually exclude each other ("Die Abwesenlleit aller egoistischen Motivation ist also das kriterium einer Handlung von moralischem Werth." , , then our task is to examine briefly the disinterested morality which reveals itself in justice, charity and self-renunciation.

In the first place. Schopenhauer believes that all virtues flow from justice (die Gerechtigkeit) and charity (die Menschenliebe) each of which have their root in compassion (das Mitleid)." As such, therefore. justice and disinterested love are the cornerstones of ethics. Justice is the first state in the path to salvation because in authentic justice the suffering of another becomes one's motive insofar as it counteracts egoistic and malicious motives preventing one from causing suffering to another and becoming the cause of another's pain. '"

It is important to note that one is motivated to be 'authentically' just not because of a set of reasoned dogmas, religions, myths, concepts or education. Rather, 'authentic' justice is connected with compassion which is "an undeniable fact of human consciousness. . [a knowledge which is] 'original and immediate' (ursprünglich und unmittelbar) residing in the depths of human nature."5 The just man (der Gerechte) is he who has realized in a partial manner that the other person is what he himself is. Given this knowledge, he is motivated to act differently. Neminem laede (harm no one) becomes a reality for him. Enlightened by this new knowledge, the path to disinterested virtue in principle becomes possible. For as Schopenhauer writes:

Genuine goodness of disposition, disinterested virtue, and pure nobleness of mind . . do not come from abstract knowledge. But it is a direct and intuitive knowledge that cannot be reasoned away, or arrived at by reasoning; a knowledge that, just because it is not abstract, cannot be communicated, but must dawn on each of us. It therefore finds its real and adequate expression not in words, but simply in deeds, in conduct, in the course of a man's life."

The just man, therefore, is not just because he fulfills the requirements which society sets as a mini- 
mum for justice. No, a man is just because the suffering of another has become his motive for different behavior. He no longer is affected merely by his own suffering. Now the sight of another's suffering and pain moves him to such an extent that he will not consciously and willingly cause another's misery. His compassion will be such that the knowledge he now has will prevent him "from being the cause of another's pain."

Clearly willing has not disappeared in the just man. Though he has begun to see through the principle of sufficient reason insofar as he places others on his level and sees them on equal terms, the process of denial of the will-to-live is by far incomplete. "The just man", writes Copleston, "has penetrated the principle of individuation, the veil of Maya, to the extent of setting others so far on a level with himself that he does them no injury; but he has not risen to the height of looking on others as one with himself, his penetration of the illusion of individuality is as yet very limited."

The man who has advanced to the stage of love (die Menschenliebe) has advanced to another plateau in the Schopenhauerian Weltanschauung. He will go beyond the just man who "never in the affirmation of his own will goes to the length of denying the will that manifests itself in another individual .. " "s Quite logically. the distinction between his ego and that of another is not as great. Less shackled to the principle of sufficient reason, the noble person (der Edle) is he whose intuitive knowledge has bridged the chasm between himself and others." He differs from the just or good man in that his compassion not only restrains him from injuring another, but moves him to actively aid the one in need." In him the maxim omnes quantum potes juva becomes a reality.

At first glance it may seem that the positive actions of the latter differentiate the two stages. But, upon analysis, it is the knowledge (die Erkenntnis) which the individual has that distinguishes the two stages. The knowledge of the 'noble' man is different in that he has grasped more profoundly the nature of the blind craving of the will. Schopenhauer describes the noble person:

The principium individuationis, the form of the phenomenon, no longer holds him so firmly in grasp (befängt ihn nicht mehr so fest) (my emphasis], but the suffering he sees in others touches him almost as greatly as does his own. He therefore tries to strike a balance between the two, denies himself pleasures, undergoes privations, in order to alleviate another's sufferings. He perceives that the distinction between himself and others, which to the wicked man is so 
great a gulf, belongs only to the fleeting and deceptive phenomenon. He recognizes immediately. and without reasons or arguments, that the initself of his phenomenon, is also that of others, namely the will-to-live which constitutes the inner nature of everything, and lives in all; in fact, he recognizes that this extends even to the animals and to the whole of nature; he will not cause suffering even to an animal. ${ }^{2}$

Because he is so acutely aware of another's suffering, the noble person is moved to go out of himself toward the other. Insofar as his actions are not motivated by his own weal, as such they can be called 'disinterested'. It is this recognition of the suffering of another which leads to charity (agape, caritas). In Parerga and Paralipomena Schopenhauer states that it is compassion (des Mitleid) "which alone is the drónn to which the gospel summons us."

Hence, it is in compassion as manifested by positive actions that the barrier between individuals is abolished ("die Schranke zwischen Ich und Nicht-Ich für den Augenblick aufgehoben sei"i") ${ }^{54}$ One no longer looks at the other as alien. As schopenhauer writes: "On the contrary, I share the suffering in him (in ihm leide ich mit), in spite of the fact that his skin does not enclose my nerves." "s

Now, whether what is described above is possible is a valid question. For even according to the logical implications of Schopenhauer's world picture, a disinterested morality does not seem possible. If it is the case that the knowing subject can never know the will totally in itself being that the form of time remains even in the new, intuitive form of knowing, it is valid to infer that no one can ever completely transcend the principle of individuation. If the principle is what brings man to his egoism, it would follow that one can never completely discard his chains. As such, a totally disinterested morality is impossible. We can only speak of a disinterested ethics in terms of degrees. For experience tells us that many so-called 'loving' actions are indeed seldom entirely selfless. The scalpel of Truth invariably reveals subtle motivations.

Notwithstanding the fact that disinterested love would warrant the plaudits of all, there is another plateau to be scaled on the road to salvation: the stage which results in a self-denying and rigorous asceticism." For the ascetic knowledge of reality has become so profound that disinterested moral actions are no longer enough. The intuitive knowledge he has of reality compels him to advance beyond Menschenliebe. Wishing the best for the other no longer satisfies the aridity of his spirit. For his knowledge has become so advanced that he alone realizes that what he is in the 
depths of his being is what the whole of reality is: namely, the continually striving will. But because he also comes to know that this will is an evil force, existence becomes perplexing and loathsome for him. Thus, his will turns on itself and begins to deny its evil essence. Calling this phenomenon the "transition from virtue to asceticism" (der Ubergang von der Tugend zur Askesis), Schopenhauer writes that it is no longer enough for (the ascetically inclined] to love others as himself, and to do as much for them as for himself, but there arises in him a strong aversion to the inner nature whose expression is his own phenomenon, to the will to live, the kernel and essence of that world recognized as full of misery." 97

The ascetic, therefore, will begin to deny or mortify his body which is healthy and strong. An initial step to the mortification of the body is the renunciation of any sexual satisfaction. For, as Schopenhauer explains, "voluntary and complete chastity is the first step in asceticism or the denial of the will-tolive." Having recognized the inner nature of existence, it is he who rejects any possibility of perpetuating the misery of the world through sexuality. Sexuality, as the chief expression of the metaphysical will, is evil. Schopenhauer even makes the conjecture that since all phenomena are interlinked, were the ascetical maxim to become universal. lower manifestations of the will would likewise disappear."

Schopenhauer's hypotheses here again are difficult to accept. Quite obviously, the strong attraction of the sexual impulse seems to preclude the possibility that the ascetical maxim become universal. Moreover, it does not necessarily follow that, with hypothetical destruction of the highest manifestation of the will. the lower manifestations would likewise disappear. Life, as we know it, would simply be different.

But be that as it may, the important notion is that chasity and celibacy are the first stages of asceticism. But the chastity and celibacy which Schopenhauer advocates are rooted in the inherent worthlessness of existence.

The ascetical state is further enhanced when voluntary and intentional poverty arise as ends in themselves $1 \%$-so as to mortify the will. The ascetic then welcomes any suffering that will come to him either through chance or wickedness. For, as Schopenhauer writes, "he gladly accepts them as opportunities for giving himself the certainty that he no longer affirms the will, but gladly sides with every enemy of the will's phenomenon that is his own person."101 The ascetic will go to the extent of fasting, selfcastigation, and self-torture for the purpose of further breaking down and killing "the will that he recognizes and abhors as the source of his own suffering existence and of the world's."102 Eor all practical pur- 
poses, therefore, the will as such will have already been crushed when death finally comes--the death which the ascetic will accept as "a longed-for deliverance". 103

By way of emphasis and clarification, Schopenhauer in no way implies that the ascetic is unhappy. Quite the contrary! Because the ascetic has reached the state of nirvana, Schopenhauer believes that only he is truly happy. The great pessimist who indulged in the pleasures of life, wistfully wonders about this plateau of salvation, stating:

- . how blessed must the life of a man whose will is silenced not for a few moments, as in the enjoyment of the beautiful, but for ever, indeed completely extinguished, except for that last glimmering spark that maintains the body and is extinguished with it. Such a man, who after many bitter struggles with his own nature, has at last completely conquered, is then left only as a pure knowing being, as the undimmed mirror of the

For the ascetic, therefore, the world with all its multiplied phenomena--with all its galaxies and milky ways-is 'nothing' (Nichts). los However, this is not to say that the word 'nothing' is to be taken literally. Schopenhauer is describing an experience-a phenomenon--which transcends the realm of philosophy proper because in this high stage of denial of the will-to-live, subject and object become one. Phenomenal knowledge (by which one sees reality as diverse and multiplied) is swallowed up by the higher intuitive knowledge one has to such an extent that the phenomenon does seem to be 'nothing' in comparison to the revelation one has received of will.106

The older Schopenhauer in no way implies that 'nothing' is the end result of the nirvanic experience of the ascetic. Insofar as individuality is not dependent solely upon the principium individuationis, but upon the thing-in-itself as well, io it follows that the experience of the ascetic does involve a something that is real--but a 'something' which eludes the philosopher's linguistic grasp. clearly, the ascetic has been illuminated. Reality for him appears radically different. Thus, what he sees now makes what he formerly saw appear as 'nothing'. '0"

With complete denial of the will being the only path to deliverance from the fierce grasp of the will. Schopenhauer believed that his philosophy alone pointed the path to salvation in a language free of mythical and religious overtones. For as he writes:

- . it may be that the inner nature of holiness, self-renunciation, of mortification of 
one's own will, of asceticism, is here for the first time expressed in abstract terms and free from everything mythical, as denial of the willto-live (die Verneinung des Willens zum Leben). which appears after the complete knowledge of its own inner being has become for it the quieter of all willing. On the other hand, it had been known directly and expressed in deed by all those saints and ascetics who, in spite of the same inner knowledge (geicher innerer Erkenntnis), used very different language according to the dogmas which their faculty of reason had accepted, and in consequence of which an Indian, a Christian, or a Lamaist saint must each give a different account of his own conduct, but it is of no importance as regards the fact... it is all the same. 109

Schopenhauer, therefore, is making two central claims: (1), that his philosophy of the denial of the will-to-live is an abstract, myth-free explanation of the path which culminates in self-denying asceticism; and (2). that the asceticism of the philosophicallyenlightened is the same as that of the Indian, Christian, or Lamaist saint. Each, in his opinion, have the same inner knowledge. But are they the same? Are not Höffding and Copleston correct in maintaining that Schopenhauer's ethic is not motivated by a higher end (e.g. the beatific vision of God, blessedness in a future life, re-absorption into the Absolute, or union with the One)? 110

\section{I}

Because Schopenhauer claims that his philosophy of the denial of the will-to-live is identical with that of genuine Christianity.il his assertions directly bear upon the reflective glances of theologians. In The World as Will and Representation he writes that the ascetical spirit of genuine Christianity was present in the writings of the earliest Christian communities:

Christianity is nearest at hand, the ethics of which we have mentioned, and leads not only to the highest degree of charity and human renunciation. The germ of this last side is certainly present in the writings of the Apostles, yet only later is it fully developed and explicitly expressed. 112

In his analysis of Christian asceticism, Schopenhauer was aware of the fact that Christian spirituality developed via certain stages. He knew that the intense mortifying asceticism espoused by his philosophy was not present in the earliest Christian writings. Citing 
several Christian ascetics such as Francis of Assisi. Philip Neri. Madame de Guyon, and Meister Eckhart, 113 he implicitly inaintains that the New Testament as such did not advocate a mortifying asceticism, as did, for example, the Desert Fathers. "In my opinion", states Schopenhauer, "the teachings of these Christian mystics are related to those of the New Testament as alcohol is to wine, in other words, what becomes visible to us in the New Testament as if through a veil and mist, stands before us in the works of the mystics without cloak or disguise, in full clearness and distinctness." 124

Schopenhauer, therefore, implies that there has been a nuancing of Christian spirituality as the centuries came and went. True, early Christianity did advocate a disinterested morality.is But what Schopenhauer underscores is that it was only after the third century that asceticism as an ideal was 'emphatically urged'. 'lic

Nevertheless, Schopenhauer clearly claims that the seed for a later flowering of Christian asceticism was already present in the gospels and New Testament writings. "il Many of the qualities characterizing the ascetic ideal were already espoused by the early Christian communities. Writes Schopenhauer:

We find commanded by the Apostles love for our neighbour as for ourselves, returning of hatred with love and good actions, patience, meekness, endurance of all possible affronts and injuries without resistence, moderation in eating and drinking for suppressing desire, resistence to the sexual impulse, even complete if possible for us. Here we see the first stages of asceticism or of real denial of the will; this last expression denotes what is called in the Gospels denying the self and taking of the cross upon oneself. (Matt. xvi, 24, 25; Mark vii1, 34, 35; Luke ix, 23, 24; xiv. 26, 27, 33.) This tendency soon developed more and more, and was the origin of penitents, anchorites and monasticism, an origin that in-itself was pure and holy, but for this very reason, quite unsuitable to the great majority of people. 13

In later additions to The World as Will and Representation Schopenhauer cites several New Testament passages which, in his eyes, recommend genuine and pure celibacy'--the first step in authentic denial of the will-to-live."' He adds also that, though marriage did receive the sanction of the Church as a 'concession' for those who lack the strength to aspire to the ideal, celibacy and virginity are the ideal through which one enters the 'ranks of the elect' and attains 'the victor's crown'.220 
As far as the injunction to voluntary poverty is concerned, Schopenhauer belleved that the sermon on the Mount contained "an indirect injunction to voluntary poverty and thus to the denial of the will-to-live."12i

Interestingly enough, however, Schopenhauer does not give any example from the New Testament advocating physical mortification and hatred of the body. Implicitly, then, he seems to be aware of the fact that the New Testament does not advocate the above as an ideal in-itself. In on the Basis of Morality he states only that New Testament spirituality propounds a disinterested morality citing Matthew $6: 3$ as an indication of the above.122

We can agree with Schopenhauer's contention that the New Testament contained implicit references to celibacy, voluntary poverty, and disinterested morality. But it is difficult to follow Schopenhauer's assertion that bodily mortification in itself is a Christian ideal, particularly during New Testament times. Schopenhauer, however, it may be stressed, is not prepared to categorically admit that his doctrine of the denial of the will-to-live is identical with the main line of Christian spirituality as found in the New Testament. He merely contends that affinities exist.

Eor, in the first place, Schopenhauer cannot accept the relationship between the old Testament and the New Testament. Like the early Christian Gnostics, who found it difficult to reconcile the New Testament with the old, 123 Schopenhauer finds it impossible to adhere to the mavia $k \alpha \lambda \alpha \lambda\{\alpha \nu$ of the Book of Genesis. Since he cannot accept the doctrine espoused by both the old and New Testament concerning the essential goodness of creation, it is understandable why schopenhauer believed that the Gnostics in their extreme idealization of celibacy and chastity were in keeping with what he called "the spirit of the New Testament". 124

Nevertheless, Schopenhauer is right when he asserts that with the passage of time asceticism became, in fact, the ideal. Emphasizing the superiority of virginity and continence over legitimate marriage, it became the Christianity par excellence.12s Though Scripture says that creation is good (Genesis 1). Schopenhauer correctly notes that the Church Fathers are often ambiguous. For on the one hand they write that the whole of creation is good--which presumably includes sexuality and marriage. On the other hand, he notes that the Eathers see abstinence as the ideal. Why the discrepancy? Schopenhauer cites a number of references from the writings of clement of Alexandria, Tertullian. Athanasius, and Augustine as examples of the above ambivalence. izc

At this point, then, it should be evident that what Schopenhauer basically is claiming is that the ideal Christian spirituality is that of asceticism notwithstanding its insistence upon the goodness of creation. 
But it is important to note that what Schopenhauer has in mind is primarily the often negative asceticism which arose in the third, fourth and fifth centuries of the Church's history.127 Since much of traditional Christian spirituality did tend to emphasize the overly negative aspects of life," Schopenhauer's contentions cannot readily be dismissed. For it can be substantiated that Cliristian tradition has been characterized by an unhealthy attitude to what is human in man-especially in the area of sexuality.129

From the above discussion one can see why Schopenhauer was convinced that his doctrine of the denial of the will-to-live could be considered a 'Christian philosophy' in a demythologized sense. For if authentic Christian asceticism is perceived to entail a renunciation of life because of its intrinsic evil, one can see certain affinities between Schopenhauer's philosophy and the sometimes negative view of life espoused by certain forms of asceticism in the history of Christianity.

The question remains, however, whether the above demythologization is interpretative or destructive. To what extent does schopenhauer have justification for his claims? It is this issue that must finally be addressed.

\section{VIII}

It cannot be denied that asceticism had replaced martyrdom as the Christian ideal by the middle of the fourth century. ${ }^{30}$ With the recognition of Christianity as the official religion, the great persecutions ended. Because the minds of fourth-century Christians were still governed by the memories of the martyrs who died for the faith, it is not at all surprising that the new ideal of fleeing to the desert to pursue holiness was seen as the new martyrdom by which the demons of hell were trampled under foot.131

Though it is true to say that ascetics devoted to prayer, chastity, and fasting were already recognized and respected groups within Christian congregations by the end of the second century, ${ }^{132}$ the asceticism of the third, fourth, and fifth centuries became an increasingly complex phenomenon. For the imitation of Christ was no longer the only motivation for ascetical behavior. Though it remained the primary motivation, there occurred a tendency of considering mortification not merely as a discipline for the soul, but as a means for its release. The desert was seen as the ideal place to attain to that mortification impossible for the city dweller. Those who went to the desert, therefore, began to comprise an elite. For as Owen Chadwick states: "If the body is the enemy, those who torture it must attain a holiness impossible to those who con- 
tent themselves with the mitigated restraints of reasonable self denial." is"

But, if true Christian spirituality entails union with God or imitation of Christ, "34 why was withdrawal from the world seen as so essential? Is it merely because the lack of a threat of persecution opened the way for a lax Christianity? Another important factor seems to be involved--as several scholars have asserted. 13 s

There evidently occurred a complex shift in world outlook sometime between the second and third centuries--a change which resulted in the intense otherworldliness of the fourth and fifth centuries.136 As Jonas has substantiated in his study on Gnosticism, "the sublime unity of the cosmos and God [was] broken up, the two [were] torn apart, and a guif never completely to be closed again [was] opened."137 The cosmos in effect became negatively charged and was emptied of its divine content.

E. R. Dodds in Pagan and Christian in an Age of Anxiety likewise argues that with the progressive withdrawal of divinity from the phenomenal world, there ensued a corresponding devaluation of the human. Contempt for the human condition, writes Docids, "was a disease endemic in the entire culture of the period". manifesting itself not only in Christian and Gnostic circles, but in pagan centers as well."

Given the radical change in world outlook that had been evolving during the early centuries of Christianity, the popularity of the semi-dualistic Sentences of Sextus ${ }^{\prime \prime}$ even among less-educated Christians during the third century is more easily understandable. Notwithstanding the fact that origen found the maxims congenial to his way of thinking, had the new world outlook (which had been slowly evolving) not affected Christians of the third century and following, it is doubtful that the maxims would have survived as a collection of highly 'admired 'Christian' aphorisms.

In short, union with God entailed withdrawal from the material world. Because the sacramental use of it was de-emphasized, it is understandable why asceticism became the spirituality par excellence. For it was the ascetic who truly divorced himself from the encumbrance of the phenomenal world. It was he who had mustered the fortitude necessary to accept the consequences of longing to reach God. Wiles sheds light on this matter:

If progress in the vision of God is directly proportionate to the measure of man's withdrawal from the things of this world, then the genuinely religious man has no option but to adopt the life of a solitary hermit. So there grew up an ideal of ascetic piety in which man seeks the eradication of the passions, seeks consciously to rid 
himself as far as possible of all that is naturally and distinctly human. 140

Hence, Schopenhauer is on target when he contends that asceticism became the spirituality par excellence by the latter part of the third century. This can be stated regardless of the fact that Schopenhauer does not take God as seriously real in his world picture. For there was a deprecation of the phenomenal world in the milieu of the times which led to the belief that the ascetic who shunned the phenomenal world to attain union with God was indeed living the superior calling.

In confunction with the above, Schopenhauer is right in asserting that virginity and cellbacy became the cornerstones of the ascetic ideal. For, as Pourrat contends, the earliest form of asceticism most widely observed was the practice of continence freely chosen by certain members of both sexes. 241 Chadwick. moreover, states that by the second century virginity was beginning to appear as ". . . the act of asceticism par excellence.. . "142

Moreover, there was especially in the third century a tendency in some Christian circles to link hope for the glory of God with the injunction to sexual purity. "1"1 In an age where the lines between orthodoxy and heresy were still blurred, living like the angels became an ideal espoused by some Church Fathers already in the late second and third centuries. Minucius Felix in The Octavius. for example, wrote of the Christians of his time: ". . the desire /referring to unfaithfulness and fornication] is so far from our thoughts that some even blush at the idea of a chaste union. "in. The fifth century Sayings of the Fathers are replete with this ideal. as are the Conferences of Cassian. ins Even Ambrose, the great bishop of Milan, advocated the above ideal. ins

This negative attitude toward sexuality is evident in the apparently common phenomenon of Christians taking Matthew 19:12 too literally. Though selfmutilation was never condoned, it is interesting to note that there was much ambivalence concerning the matter. ${ }^{147}$ For example, Eusebius (c. 265- c. 340), though not condoning Origen's supposed self-mutilation, appears to at least praise his misguided zeal for the gospel.'. Justin Martyr, living in the mid-second century, recounts the story of a young man who petitioned the perfect Felix in Alexandria for permission to be made a eunuch. ${ }^{149}$ He likewise seems to have an admiration for such misguided zeal. Even John Chrysostom (334-407), while bitterly attacking the practice, at least gives valuable information concerning the practice which must have still been a problem during his day. 150

Thus, when Schopenhauer alludes to sexuality as the chief hurdle to be overcome on the path to denial of 
the will-to-live, he is in line with many of the early Christian ascetics who often went to the point of the ridiculous to preserve their chastity. ${ }^{131}$ Pourrat contends that it was impurity (nopvel $\alpha$ ) which was the vice most dreaded by the monks of the desert. ${ }^{132}$ The eccentric Jerome $(349 ?-420)$ is a case in point. Struggling with temptation, he writes:

I was often surrounded by dancing girls. My face was pale from fasting, and my mind was hot with desire in a body as cold as ice. Though my flesh, before its tenant, was already as good as dead, the fires of the passions kept burning within me. 153

Corresponding to the ideal of strict chastity and virginity was the patristic depreciation of the body and the worldly. Keeping in mind the chasm that had arisen between God and the phenomenal world, one is more apt to understand why the body was considered a prison of the soul by many ascetics. ${ }^{134}$ Chadwick writes that the "semi-dualistic atmosphere inherited from pagan philosophy drove some ascetics to think they must blame the body, that the body held the soul bound and imprisoned in its tomb, and therefore the mortification aimed at a physical object, the laceration and repression of the body that the soul might be freed."1ss The body was such an encumbrance, thought origen, that be believed that the Holy Spirit was not only absent in conjugal intercourse, but in other physical activities as well. 156

In order for anyone to reach a state of holiness, therefore, the body had to be crushed by physical, self-imposed crucifixion. Interpreting Mathew 11:12 ("From the days of John the Baptist until now the kingdom of heaven has suffered violence, and men of violence take it by force." RSV) as a scriptural justification for their harsh practices, some Eathers believed that the greater the violence done to themselves, the nearer they were to the kingdom of God." fasted to the point of unhealthy excess in their desire to kill the flesh. 130

Einally, just as the ascetic in Schopenhauer's critique welcomes death as the final liberation from the thraldom of the will, so too are there elements in the Christian tradition that, while considering death as the final step to perfection, likewise believed it to be a liberation. Death becomes almost a formality to be passed through. For the greatest part of killing the flesh has long been accomplished. The ascetic. therefore, welcomes death peacefully. ${ }^{15}$

From this short inquiry, there are at least some elements in Schopenhauer's philosophy of the denial of the will-to-live that are interpretative of certain strata within Christian asceticism. It is clear that 
much can be found in the Christian tradition (especially in the third, fourth, and fifth centuries) that downplays the phenomenal order and the physical aspect of man. Schopenhauer recognized this and was right in bringing it to the attention of all.

IX

However, despite the separation between God and the cosmos that ensued and the resulting devaluation of human experience that occurred as a result, it is important to note that God was never left out of the ascetics' picture. Though otherworldly and transcendent, He was always taken as seriously real and the object of their striving. Schopenhauer, on the other hand, albeit he admitted the possibility of a theism, does not really take God as seriously real. God is not the motivating force in or the basis of Schopenhauer's ethics. It is precisely here that an impasse has been reached.

According to Cliristian spirituality, it is God's reality which ultimately is the focal point for ethical action--notwithstanding the ideal of doing goodness for the sake of goodness alone. For if one begins by examining the teaching of Jesus--even though such an endeavor is incidental to this inquiry--Jesus' theocentric view of life serves as the basis for his entire ethic.160 A brief examination would be illuminating.

The cornerstone of Jesus' teaching, of course, is his proclamation of the Kingdom of God: "The time is fulfilled and the kingdom of God is at hand; repent and believe in the Gospel." RSV (Mk 1:15). In fact, the concept of a personal, loving God is presupposed through the entirety of Jesus' teaching to such an extent that he sees no need for a rational foundation for his ethics.161 Thus, it is not pity for the miseries of another, induced by a consciousness of one's own, that results in love of neighbor--that effects the new righteousness. Rather, love for neighbor grows out of a stance--a state of being--rooted in God in expectation of His future."1"2 "It is", as Schnack enburg writes, "the foundation of this utterly resolute love for God that love of the neighbor is built up."is"

Authentic Christian piety, therefore, is rooted in and directed toward God. The one giving alms should not sound the trumpet before him so that all might marvel at his magnanimity of heart (Mt. 6:2). The one praying should do so in the privacy of his room so that only God sees him (Mt. 6:5). And the one fasting should not make an ostentatious show of himself (Mt. $6: 16)$. In short, authentic piety is to exist for God as a slave would for his Lord (cf. Lk. 17:7 ff.). Such a piety clings to God with an 'unreserved confidence' and lives 'by His hand'.164 
An analysis of The Sayings of the Fathers reveals a continuity with the teaching of Jesus insofar as the theocentric view of life so integral to Christianity is maintained. The following quotations from the corpus of the aforementioned collection casts light upon this fact:

Abba Hyperichius said: "Let your mind be ever upon the kingdom of heaven, and you will soon win its inheritance."

Abba Poemen said: "A man ought ever to be absorbing humility and the fear of God, as the nostrils breathe air in and out."

A brother asked Abba Sisois: "I observe my own mind and $I$ see that it is recollected and intent upon God." And the old man said to him: "There is no great thing that your mind should be with God. The great thing is to see ourself to be lower than every created being. Bodily toil will put it right, and will lead you on the way to humility."ics

It is apparent, therefore, that the theocentric view of life remained characteristic of the monks of the desert despite the negativism that had crept into their spirituality. John Cassian's Conferences buttress the point I have been trying to make. ict And, by way of adding icing to the cake, the Rule of Saint Benedict did not encounter any difficulty winning acceptance because of its theo-christocentric characterif but because of its lax spiritis.--which certainly sheds light upon the period in question!

Hence, though Schopenhauer is right in stressing the negative character of early Christian asceticism, even an overly negative Christian asceticism is not willing to part with its otherworldly and transcendent God. For to do so would shatter its distinct character. The God of the ascetics was someone very real indeed!

In conjunction with what has been said above, it necessarily follows that authentic Christian asceticism receives its impetus from the reality of God's presence. Aversion to material realities is not the primary motive leading to ascesis. A reference to the historical figure Jesus shall again be necessary.

First of all, from all indications, Jesus was no ascetic, as was John the Baptist. 's Viewing his ministry as a time of release from normal religious obligations and as a time of rejoicing, Jesus, while not denying the validity of Jewish religious and fasting practices, did not believe that his followers should fast while 'the bridegroom' was present (Mt. 9:14-15; Mk. 2:18-20; Lik. 5:33-35). Imbued with a sense of the impending sovereignty of God (hereinbrechenden Gottesherrschaft), Jesus' life-style and demands were per 
se not ascetical.170 He was, therefore, open to the charge of the Pharisees that he was a glutton, drunkard, and friend of sinners and tax-collectors (Mt. 11:19). And though he did call some individuals to special discipleship, the special demands made on the disciples (Lk. 14:28-33; Lk. 14:16 ff.) cannot be considered as a code for a moral elite. 13

Jesus' demands were made only in light of the challenge of the hour. True, following Jesus did involve self-renunciation, openness to the possibility of persecution--but only because of the kingdom of God.172 It is only because of the kingdom that a man sells everything be has to buy the field in which he has found a treasure (Mt. 13:44). It is because of this kingdom that a merchant will sell all he has to obtain the pearl of his longing (Mt. 13:45). Poetic images aside, it is clear that the motive for renunciation in Jesus' teaching was not the worthlessness of life, but the all-encompassing sovereignty of God which develops irresistibly like yeast in bread (Lk. 13:20-21) and the mustard seed that grows into a great tree shielding the birds of heaven (LK. $13: 18-19$ ).

In light of the above discussion, it is clear that Jesus never condemned bodily realities for what they were in themselves. In all likelihood, he would have been horrified at the way some of the desert fathers were using scripture to justify their severe penances (refer to footnote 157). Perrin's exegesis of Mk. 7:15 ("). . there is nothing outside a man which by going into him can defile him; but things which come out of a man defile him.") is particularly illuminating in this study. Concerning its significance, Perrin writes:

The Jesus tradition flatly denies that there are any external circumstances in the world or of human life which can separate a man from God; a man can be separated from God only by his own attitude and behavior. Not the world, nor life, but only man himself is the 'defiling' agent. This is perhaps the most radical statement in the whole of the Jesus tradition and, as such, it is certainly authentic. ${ }^{13}$

Though Jesus never condemned material realities for what they were in themselves, he chastised those who relied exclusively on them (Lk. 12:13-21) in view of the sovereignty of God. In line with the above, he never condemned marriage. He praised it, considering it a lighly dignified manner of testifying to one's approval of creation, and distinguished it froin celibacy only insofar as the latter prefigures the goal of the kingdom. ${ }^{174}$

From this brief analysis of Jesus' ethic, it is evident that Jesus' call for renunciation is based only upon the Lordship of God, which requires of everyone a 
radically new attitude to life in the world. In no way is renunciation an end in itself. For the goodness of creation is always maintained.

An analysis of the early Christian communities reveals a similar tendency--especially in the case of the Pauline communities. Although Paul was convinced that the Parousia was imminent, no ascetic program had been developed in these early Christian communities. Conzelemann succinctly summarizes his ideas on this matter in the following passage:

That no ascetic principle had been developed is clear from three areas: (a) food; fasting is not ascesis, but is determined by ritual. True, ascetic trendencies emerge here and there, but they are rejected, for the earth is the Lord's and all that is in it ( 1 Cor. 10-26; cf. Rom. 14:14, 20; 1 Tim. 4:3f.). (b) sexual ascesis: Paul approves of it in view of the dangers attached to it. But he does not make any law (1 Cor. 7); (c) possessions: riches are not in themselves evil, they are dangerous . . .'s

Once again, therefore, it is evident that, though ascetic tendencies may have their root partly in New Testament writings, in no way are phenomenal realities condemned for what they are in themselves. It is God's sovereignty and/or the imminence of the Parousia that calls for a new attitude toward them. Again, the motivation for renunciation is not an end in itself.

Proceeding along these lines, one does not need a sharp eye to discover many examples in patristic literature that illustrate that ascetical behavior in Christian literature was primarily motivated by a desire to attain union with God. For example, Ignatius of Antioch (?-107) renounced his life only because he desired to be united with Christ. Bouyer writes that Ignatius "evidences no trace of hatred, no misprising, of life or of creation."izc

With regard to the later desert Fathers, it, of course, cannot be denied that much negativism characterized their thinking, given the milieu of the times. But even they kept God as the ultimate goal of their striving and as the end of their sometimes bizarre ascesis.177 Though it is correct to point out that in some cases the proper motivation for their ascesis was blurred, their self-renunciation, generally speaking, was not primarily or solely motivated from a hatred of material realities.

Moreover, despite their depreciation of the phenomenal order, it is important to note that they could still appreciate the majesty of creation because of this God they sought. 17 Even the eccentric and acidtongued Jerome, notwithstanding his austere and callous 
bent, urged a hesitant Heliodorus to withdraw to the desert--eyes dry--to take up the cross of Christ.17s

clearly, therefore, there is an essential difference between classical Christian asceticism and the self-denial advocated by Schopenhauer. If one eliminates the important fact that Christian asceticism is motivated for the sake of God, what would ensue as a result would be an asceticism similar to the one propounded by Schopenhauer. But such a reductionism would, needless to say, be totally contrary to the nature of Christian asceticism. In this regard, therefore, Schopenhauer's demythologization of christian spirituality is destructive.

But it is destructive in two other key areas which also warrant brief consideration. The first concerns Schopenhauer's metaphysic, which presupposes an ontological pessimism. The second pertains to schopenhauer's contentions that the individual can attain a 'salvation' of a sort on his own. Both notions, however, are clearly rejected by classical Christian spirituality.

Although the world and man do not appear to be good from an empirical point of view, they are from the standpoint of God--as Conzelmann ascertains. though such a statement does little to convince the philosopher wrestling with the problem of evil, a Christian asceticism which believes in the Creator God cannot opt for a metaphysical pessimism. Eor it would thereby sever itself from its cornerstone: faith in a good God.

Thus, if a metaphysical pessimism is out of the picture, matter pex se is not sinful. And if matter is not per se sinful, death in-itself--at least in the Christian framework--has no liberating power of its own. It is that which lies beyond that does. Hence, death is but a step toward perfection in Christian asceticism. In Schopenhauer's Weltanschauung, however, it is the final deliverance.

It is interesting to note that metaphysical pessimism was rejected from the beginning with Paul, the apostle to the Gentiles. In his juxtaposition of 'flesh' and 'spirit' he never taught that man was a sinner because of his corporeality.'1 Denying even that the 'inner man' was closer to God than the fleshly man, he affirmed the neutrality of the anthropological (ofiua) and cosmological (kóowos) concepts in his theology. $1: 2$

Later Church Fathers remained true to the Scriptures and defended the inherent gooduess of creation against Gnostic and Encratite teachings. For example. Irenaeus (A.D. 120-202) condemned the Encratites for downplaying the dignity of marriage for ingratitude to God because of their aversion to material realities.' ' John Chrysostom in the fifth century argues with those who "accuse the workmanship 
of God, and take part with the Manichees... " 180 And the Council of Braga (A.D. 561) categorically condemns adherents of metaphysical pessimism.i's

With regard to the ability of the individual to attain salvation on his own, Schopenhauer's contentions that the individual has the dynamism within himself to achieve salvation are not in conformity with general Christian belief. For holiness is not so much a result of moral effort alone, but it is a gift from God in authentic Christian spirituality."io

In this regard, continence and/or celibacy are considered to be special gifts from God not given to all (1 Cor. 7:7; Mt. 19:11). Schillebeeckx underscores this when he writes: "The difference between Christian and pagan ideals of continence lies at the outset exclusively in the acknowledgement of saving grace . . . "is John Cassian's Conferences make the same point: "Perfection in the full sense is a gift of God, and it is rare indeed. "I".

But since Schopenhauer has severed God from his world picture by not taking Him seriously, holiness for him is the result of moral effort alone. The ascetic, for example, in Schopenhauer's system is illumined by the grace of a transcendent God. Quite logically, therefore, continence and/or celibacy in the Schopenhauerian Weltanschauung are not considered gifts from God. Ascetical self-denial arises solely from intuition into the nature of the will which has objectified itself in the totality of reality. Herein, therefore, lies another decisive reason for maintaining that Schopenhauer's demythologization of Christian asceticism is destructive.

\section{NOTES}

'Maurice Mandelbaum, History, Man and Reason (Baltimore: John Hopkins Press, 1971), p. $3 \frac{\text { and }}{12}$.

${ }^{2}$ Harry J. Ausmus, "Schopenahuer and Christianity: A Preliminary Examination." Illinois quarterly (April, 1974), pp. 26-42.

'R. J. Hollingdale, Arthur Schopenhauer: Essays and Aphorisms (Harmondsworth: Penguin Books, 1970), p. 34.

"Bertrand Russell, $\Lambda$ History of Western Philosophy (New York: Simon and Schuster, 1945), p. 753 .

'Erederick Copleston in A History of Philosophy. vol. 7, part II (Garden City: Image Books, 1967), pp. 
50-51, writes: "Schopenhauer combined his enthusiasm for the Hindu philosophy of Maya with a great appreciation for the Buddha. And he had perhaps more sympathy with the Buddhist ethic than with more dymamic western concepts of altruism." In Schopenhauer: The Philosopher of Pessimism (Andover: Burns Oates \& Washbourne, Ltd., 1946), p. 212, Copleston implies that Schopenhauer's philosophy as "an extreme statement of the problem of evil and suffering" is not reconcilable with Christianity and cannot be considered to be such.

'Patrick Gardiner, Schopenhauer (Harmondsworth: Penguin Books, 1963), p. 238 .

'Arthur Schopenhauer, The Eourfold Root of the Principle of Sufficient Reason, trans. E. F. J. Payne (La Salie: Open Court Publishing Co.. 1974), p. 183. German text: Ueber die vierfache Wurzel des Satzes vom zureichenden Grunde as found in Sämmt iche Werke, ed. Grossherzog Wilhelm, 3 (Leipsic: Inselverlag, ig051910), p. 145 .

Arthur Schopenhauer, Parerga and Paralipomena. vol. I, trans. E. F. J. Payne, I (Oxford: Clarendón Press, 1974), pp. 105-106. German text: Parerga und Paralipomena as found in sammtliche werke, ed. Grossherzog Wilhelm, 4 (Leipsic: Inselverlag, 19051910). pp. 133-134.

"I owe what is best in my development to the impression made by Kant's works, the sacred writings of the Hindus, and Plato." Arthur Schopenhauer, The World as Will and Representation, vol. I, trans. E. E. J. Payne, 1 (New York: Dover, 1969), p. 416. See also Helen Zimmern, Arthur Schopenhauer: His Life and His Philosopliy (London: Longmans, Green \& Co.., 1896), $\frac{\text { and }}{\text { p. }}$ 166 .

${ }^{10}$ The four truths basically assert that the world is characterized by universal suffering and that life is inherently tragic because of the universality of desire. Only through the suppression of desire and spiritual discipline can one reach the transcendent state of nirvana. See Edward Conze, Buddhism: Its Essence and Development (New York: Harper \& Row, 1951). pp. 43-48; Thomas Berry, Religions of India: Hinduism, Yoga, Buddhism (New York: The Bruce Publishing Co.. 1971), p. 13.

"The World as Will and Representation, vol. 2, p. 169. Hereafter cited as WWR.

12 Schopenhauer calls Christianity "the doctrine of the deep guilt of the human race by reason of its very existence, and of the heart's intense longing for sal- 
vation therefrom . . . [whicll] can be attained only by the heaviest sacrifices and by the denial of one's own self, hence by a complete reform of man's nature." WWR, 2: p. 625. In Parerga and Paralipomena, 2, p. 381 (hereafter cited as $\bar{P} \bar{P})$. Schopenhauer, though not as negative, writes: For Christianity "the world is no longer an end, but a means; the kingdom of eternal joy lies beyond it and beyond death. Renunciation in this world and the direction of our hopes to a better world are the spirit of Christianity."

$$
\begin{aligned}
& \text { "WWR, 2: p. } 615 . \\
& \text { "Ibid., p. } 616 . \\
& \text { "Ibid., p. } 623 . \\
& \text { "PP, 2: p. } 201 . \\
& \text { "Ibid., p. } 321 . \\
& \text { "Ibid., p. } 315 . \\
& \text { "Gardiner, p. } 264 .
\end{aligned}
$$

2 "WWR, 1: p. 3. German text: Sämmtliche Werke, 1 Band, P. 33; hereafter cited as SW.

"By "representation" (Vorstellung) Schopenhauer means that which is only in reference to another thing. The Vorstellung essentially is a physiological process. or, to be more exact, the end result of one. In the words of Schopenhauer, it is "the end product when the understanding (Verstand) has elaborated the sense data into an object of space by applying the law of causality." Arthur schopenhauer, On the Basis of Morality, trans. E. E. J. Payne (Indianapolis: BobbsMerrill, 1965), p. 132; hereafter cited as OBM.

22 WWR, $1:$ p. 417 .

${ }^{23}$ Ibid. . p. 3.

2"The Eourfold Root of the Principle of Sufficient Reason, paragraph 21, $\frac{p}{75}$ (henceforth cited as FRPSR). It is because the understanding applies its sole form, the law of causality, that a powerful transformation takes place "whereby subjective sensation becomes objective intuitive perception. . . by virtue of its particular form and so a piiori.. . the understanding grasps the given sensation of the body as an effect (a word comprehended only by the understanding) and this effect must necessarily have a cause. simultaneously the understanding summons to its assistance space, the form of the outer sense also lying 
predisposed in the intellect, i.e., in the brain. This it does in order to place the cause outside the organism; for only in this way does there arise an outside whose possibility is simply space, so that pure intention a priori must supply the foundation for empirical perception. In this process. . . the understanding now avails itself of all the data of the given sensation. . in order to construct in space... . the cause of sensation." pp. 77-78f.

25WWR, 2: p. 194 .

26 Ibid. . P. 179 .

2'Iminanuel Kant, The Critique of Pure Reason. trans. F. M. Muller (Garden City: Anchor Books, 1966), p. 196.

2"WWE, 1: p. 436 .

29 Arthur Schopenhauer, Essay on the Freedom of the Will. trans. Konstantin kolenda (Indianapolis: BobbsMerrill, 1960), p. 11; hereafter cited as EOEW.

${ }^{3}$ WWR, 1 : P. 100.

"WWR, 2: p. 196.

32 Ibid. , p. 197.

'WWR, 1: p. 110 .

"Arthur Schopenhauer, Ueber den Willen in der Natur as found in SW, 3, p. 204 .

${ }^{13}$ WWR, 1: p. 118. German text: SW, 1, p. 176 .

"Ibid. . p. 275.

"I Ibid. , p. 308 .

"Both Atman and Brahan designate the final reality, the inner support of all beings, the one behind all multiplicity. Each has its own origin, however, in a different aspect of man's experience of reality. Atman indicates the absolute support of being, experienced subjectively as the support of a person's own existence. Brahrnan came to designate the absolute reality as this is experienced objectively as the support of the visible world. It was a great moment in the history of Hindu thought when the identity of these two was perceived: 'Thou are that', meaning that the deepest subjective reality is identical with the absolute manifested objectively in the world without." Berry, p. 12 . 
"P्P, 2: p. 281.

"WWR, 1: p. 310.

"Ibid., p. 312.

"Ibid.. p. 196. "All willing springs from lack, from deficiency, and thus from suffering. Eulfillment brings this to an end; yet for one wish that is fulfilled there remain at least ten that are denled. Further, desiring lasts for a long time, demands and requests go on to infinity; fulfillment is short and meted out sparingly. But even the final satisfaction is only apparent; the wish fulfilled at once makes way for a new one; the former is a known delusion, the latter is a delusion not yet known. No attained object of willing can give a satisfaction that lasts and no longer declines. . Thus the subject of willing is constantly lying on the revolving wheel of Ixion, is always drawing water in the sieve of the Danaids, and is the eternally thirsting Tantalus."

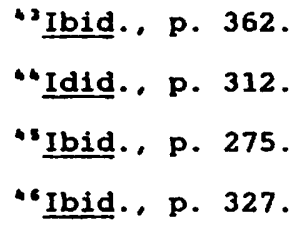

"Schopenhauer equates the will with life. As he writes, "what the will wills is always life, just because this is nothing but the presentation of that willing for the representation." WWR, 1: p. 275.

"I". . . the individual is the bearer of the knowing subject, and thus the knowing subject is the bearer of the world. This is equivalent to saying that the whole of nature outside the knowing subject, and so all remaining individuals, exist only in his representation; and so merely indirectly, and as something dependent on his own inner being and existence." WWR, 1: p. 332 .

\section{"Ibid.}

son . . . everywhere the many different forces of nature and forms contest with one antoher for the matter in which the desire to appear, since each possesses only what it has wrested from another." WWR, 1: p. 309 .

$$
\begin{aligned}
& \text { s'Ibid., p. } 337 . \\
& 52 \text { pp. 2: p. } 213 .
\end{aligned}
$$


${ }^{5}$ Ibid. , p. 215.

"Schopenhauer states that it is the principle of individuation that makes one think that he is radically different from others. Says he, "it is the knowledge to whose truth flesh and bone witness; it lies at the root of all egoism and is really expressed in every loveless, unjust and malicious action." OBM, p. 210.

ss". . . the eyes of the uncultured individual are clouded, as the Indians say, by the veil of Maya. To him is revealed not the thing-in-itself, but only the phenomenon in time and space, in the principium individuationis, and in the remaining forms of the principle of sufficient reason. In this form of his limited knowledge he sees not the inner nature of things, which are one, but its phenomena as separated, detached, innumerable, very different, and indeed opposed." WWR, 1: p. 352 .

56 Ibid. . p. 288 .

57 Kant, Critique of Pure Reason, pp. 371-379. Kant believes that he has shown that freedom and natural necessity may "exist independent of, and undisturbed by each other. " (p. 379).

s" Criticism of the Kantian Philosophy," WWR, 1: p. 504. See also the Critique of Pure Reason where Kant writes that "reason creates for itself the idea of spontaneity, or the power of beginning by itself, without an antecedent cause determining to action, according to the law of causal connection." (p. 367). Kant further states that the "practical concept of freedom is founded on the transcendental idea of freedom." (same page). In the Critique of practical Reason, trans. Lewis white Beck (Indianapolis: BobbsMerrill, 1956), pp. 55-56, Kant implies the same.

s"WWR, 1: p. 503. German text: SW, 1: p. 651.

' Ibid.

' ${ }^{1}$ EOFW, p. 94. German text: SW, 3: pp. 482-483.

2 Ibid. , p. 49.

' $\mathrm{OBM}$, p. 187 .

CWWR, 1: pp. 185-186.

cs Ibid.. p. 178 .

6 Ibid.. p. 196. 
'Ibid., p. 197.

"Ibid. . p. 156.

"Ibid.. p. 285. German text: SW, 1: pp. 380-381.

"Ibid. . p. 354.

"It is interesting once again to draw a parallel to the Upanishads which propound the universality of Brahman in the whole of reality. Thomas Berry is right when he asserts that Brahman is manifested even in the act of consciousness whereby one recognizes his own existence. Thus, denial of Brahman is to deny one's being. In Schopenhauer's system, to deny one's willto-live, is to deny what one is at the core of his being--namely will. See Berry, pp. 25-26.

12 PP, 2: P. 313 .

"Ibid. German text: SW, 5: p. 338.

TWWR, 1: p. 398. German text: SW, 1: pp. 521-522.

"Ibid., p. 399.

"Here again I have difficulty with Schopenhauer's ascribing knowledge to this will which is "blind." In Parerga and Paralipomena, the work of his later years, Schopenhauer nuances his earlier writings insofar as he claims that it is the conscious subject that wills as such. Refer to footnotes 72 and 73.

T'WWR, 1: p. 400.

"Gardiner, p. 264.

"OBM, p. 69. German text: SW, 3: pp. 526-527.

"Ibid.. p. 122.

'I Ibid.. p. 128.

'2 Ibid., p. 140. German text: SW, 3: p. 597.

" $\underline{\mathrm{S} W}, 3$ : p. 606. English trans: OBM, p. 148.

"Ibid.

"Ibid., p. 149. German text: SW, 3: pp. 606-607.

- 'WWR, 1: pp. 369-370.

' 
"Copleston, Arthur Schopenhauer: The Philosopher of Pessimism, p. 173 .

' "WWR, 1: p. 370 .

' Ibid., p. 372 .

'OBM, P. 163 .

92WWR, 1: p. 372. German text: SW, 1: p. 489.

'PP, 2: p. 202 .

9"OBM, p. 166. German text: SW, 3: p. 624.

's Ibid.

"Schopenhauer defines asceticism as "the deliberate breaking of the will by refusing the agreeable and looking for the disagreeable, the voluntarily chosen way of life of penance and self-chastizement, for the constant mortification of the will." WWR. 1: p. 392 .

'I Ibid., p. 380. German text: SW. 1: p. 498.

I Ibid.

"Ibid.

100 Ibid. , p. 381 .

101 Ibid. p. 382 .

102 Ibid.

203 Ibid.

104 Ibid. , p. 390 .

10sIbid.. p. 412. German text: SW, 1: 538 .

106 In WWR, 2: pp. 640-646, Schopenhauer delves into this problem, admitting that the experience of the denial of the will-to-live is in the realm of epiphilosophy. In PP. 2: p. 313, he writes that "we can only say that this phenomenon cannot be that of velle."

107 PP, 2: p. 227. German text: " . . die Individualität nicht allein auf dem dem principio individuationis berult und daher nicht durch und durch blosse Ercheinung ist; sondern dass sie im Dinge an sich, im Willen des Einzelnen, wurzelt: denn sein Charakter selbst ist individuell." SW, 5: p. 245 . 
"'Thomas Whittaker, Schopenhauer (New York: Dodge Publishing Co., 1909), p. 183 . 503.

109 WWR, 1: p. 383. German text: SW, 1: pp. 502-

"Harold Höffding, A History of Modern Philosophy, 2 (Toronto: Dover, 1955), p. 235; Copleston, Schopenhauer: The Philosopher of Pessimism, p. 188 .

\begin{abstract}
"'Schopenhauer writes: "For not only the religions of the East, but also true Christianity has throughout his fundamental ascetic character that my philosophy explains as denial of the will-to-live." WWR, 2: p. 615 .
\end{abstract}

$$
\begin{aligned}
& 11 \text { WWR, 1: p. } 386 . \\
& 13 \text { Ibid. pp. } 384 f . \\
& 11 \text { Ibid. p. } 387 . \\
& 13 \text { Ibid. p. } 386 . \\
& 13 \text { WWR. 2: p. } 616 . \\
& 11 \text { WWR. 1: p. } 386 .
\end{aligned}
$$

11 Ibid.

"Matth. $x i x, 11$ seg.: Luke $x x, 35-37$; 1 Cor. vii, 1-11 and 25-40; 1 Thess. iv, 3; 1 John iii, 3; Rev., xiv, 4. WWR, 2: P. 616.

220 Ibid. . pp. 616-617.

121 Ibid.. p. 633. Schopenhauer cites Matth. v, 40

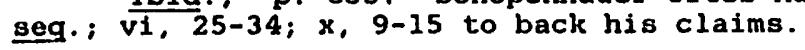

${ }^{122 \mathrm{OBM}}$, pp. 164-165. Matth. 6:3: "Let not thy right liand know what thy left doeth."

$123 \mathrm{~J}$. N. D. Kelly, Early Christian Doctrines (New York: Harper \& Row, 1960), pp. 64-69. Marcion in particular found it difficult to see the old Testament as a Christian book. This is particularly interesting because Schopenhauer himself states that it is only the 'myth' of the Eall of Man that reconciles him to the old Testament. WWR, 2: p. 620.

$$
124 \text { Ibid.. p. } 622 \text {. }
$$

125Daniel Callam, "Clerical Continence in the Fourth Century," Theological studies, 1 (1980), pp. 58 . 
126 WiVR, 2: $616 \mathrm{f}$.

$121 E d w a r d$ Lecky, History of European Morals from Augustus to Charlemagne, 1 (New York and London: $\frac{\text { (Nom }}{D}$. Appleton and Companuy, 1913), pp. $122 \mathrm{f}$.

12 Philip A. Verhalen, Faith in a Secularized World (New York: Paulist Press, 1976), p. 157 .

$12{ }^{\circ}$ Bernard Cooke, Ministry to Word and Sacraments: History and Theology (Philadelphia: Fortress Press, $\overline{1} 976), p .396$.

"Tothat martyrdom had been the ideal of Christian perfection in the early centuries of Christianity is substantiated by numerous references in praise of 1 t. See Jean Danielou and Henri Morrou, The Eirst Six Hundred Years, trans. by vincent cronin (London: Darton, Longman and Todd, 1964), pp. 124-126. That it was seen as an ideal to be sought in the final stage of Christian perfection is perhaps best illustrated by Ignatius of Antioch (d. A.D. 107?) who declared that. through his martyrdom, he would not only be "called a Christian, but also prove to be one." Ignatius to the Romans. 3, as found in The Epistles of st. Clement of Rome and st. Ignatius of Antioch, trans. by James $\bar{A}$. Kleist, vol. 1 of Ancient Christian Writers (New York: Newman Press, 1946), p. 81. But with the end of the great persecutions, fight from the world became the "most favourable if not the necessary condition for attaining perfection." Danielou, p. 269.

"'Owen Chadwick, Western Asceticism, vol. 12 of The Library of Christian Classics (Philadelphia: Westminister Press, MCMLVIII), p. 20 .

1"20wen Chadwick, John Cassian: A Study in Primitive Monasticism (Cambridge: Cambridge University Press, 1950). p. 77 .

1 Ibid.. p. 71.

"'Refer to the following works: Pierre Pourrat, Christian Spirituality from the Time of Our Lord till the Dawn of the Middle Ages, trans. by and $S$. P. Jacques (Westminster, Maryland: Newman Press, 1953), p. 6; Gustave Thils, Christian Holiness: A Precis of Ascetical Theology, trans. by John L. Earrang (Tliêtt: Lanno Publishers, 1961), p. 201; Louis Bouyer, Introduction to Spirituality, trans. by Mary Perkins Ryan (Collegeville: Liturgical Press, 1961), p. 200; Owen Chadwick, John Cassian: A study in Primitive Monasticism, p. 77; Hans Küng, Existe Dios?. tradujido al castellano por J. M. Bravo Navalpotro (Madrid: Ediciones Cristiandad, 1979), p. 942. 
13 See Knowles, David. Christian Monasticism (New York: McGraw-Hill Book Company, 1969); Chadwick, Henry. The Sentences of Sextus (Cambridge: Cambridge University Press, 1959); Chandwick, Owen. John Cassian: A Study in Primitive Monasticism (Cambridge: Cambridge Üniversity Press, 1950); Lecky, William Edward Hartpole, History of European Morals from Augustus to Charlemagne. 2 vols. (New York: D. Appleton and Company, 1913); Dodds, E. R. Pagan and Christian in an Age of Anxiety (Cambridge: Cambridge University Press, 1965); Jonas, Hans. The Gnostic Religion (Boston: Beacon Press, 1963); Houlden, J. L. Ethics and the New Testament (Harmondsworth: Penguin Books, 1970). The aforementioned works allude to a pessimism and anxiety which characterized all strata in society beginning.late in the second century.

${ }^{136}$ Chadwick, Jolnn Cassian: A Study in Primitive Monasticism. p. 3 .

13'Hans Jonas, The Gnostic Religion (Boston: Beacon Press, 1963), p. 251 .

"'E. R. Dodds, Pagan and Christian in an Age of Anxiety (Cambridge: Cambridge University Press, 1965). p. 35 .

${ }^{13}$ The Sentences of Sextus is a collection of moral maxims which was widely read among Greek Christians of the third century. Emphasizing that continence is the foundation of true piety. it espouses that true religion consists in withdrawal from the external and merely physical. For the Greek text and Latin translation not to mention an excellent critique of the collection's importance in the history of Christianity, refer to: Chadwick, Henry. The Sentences of Sextus (Cambridge: Cambridge University Press, 1959).

1"0Maurice Wiles, The Christian Eathers (Philadelphia: J. B. Lippincott Co., 1966), p. 170.

142 Pourrat, p. 36.

1"2Owen Chadwick, Western Asceticism, p. 14.

${ }^{14}$ The apocryphal text, The Acts of Paul, written by a contemporary of Tertulilan, is a case in point; for it was widely read in the third century /refer to Wilhelm Schneemelcher, Edgar Hennecke New Testament Apocrypha, vol. 2, trans. by R. Mc W Wilson (Philadelphia: Westminster Press, 1964), p. 323 for patristic sourcesl. Even with the first reading, it is striking how the motif of sexual intercourse plays such an important role in achieving salvation. A glance at a few of the "beatitudes" in the work is illuminating: 
"Blessed are they who have kept their flesh pure, for they shall become a temple of God."; Blessed are they who have renounced this world, for they shall be pleasing to God."; "Blessed are the bodies of virgins, for they shall be well-pleasing to God, and shall not lose the reward of their purity." See The Acts of Paul as found in Schneemelcher, vol. 2, pp. 354-355.

1"Minucius Felix, The octavius, 31, 5, trans. by Rudolph Arbesmann, as found in vol. 10 of The Fathers of the Church (New York: Fathers of the church, Inc., 1950), p. 388 .

${ }^{145}$ The desert was not only seen as a place of deliverance from the 'polution of this world' but also as the place where one could live 'like the angels'. The Sayings of the Eathers, V, 34, as found in Owen Chadwick's Western Asceticism, p. 70. Conference 9 by John Cassian is also illuminating: "To pray 'Thy will be done on earth, as it is in heaven' is to pray that men may be like angels . . " John Cassian, Conferences, 9, 20, as found in Western Asceticism, p. 224 .

1"Ambrose espouses a complete separation between the sacred and profane. He urges that the ministerial office be kept ". . . pure and unspotted... not.. - defiled by conjugal intercourse." [Ambrose, On the Duties of the clergy, 50, 258, as found in vol. 10 of The Nicene and Post-Nicene Fathers, edited by Rev. H. De Romestin and Rev. H. T. E. Duckworth (New York: The Christian Literature Company, 1896), p. 41.1.

'1"'W. F. Albright, Matthew, vol. 26 of The Anchor Bible (Garden City: Doubleday \& Company, 1971), p. $2 \overline{27}$.

'"Eusebius Famphil1, Ecclesiastical History, 6, 8, trans. by Roy J. Deferrari, as found in vol. 29 of The Fathers of the Church (New York: Eathers of the Church, Inc.. 1955), p. 260.

14'Justin, Apology I, 29, trans. by cyril C. Richardson, as found in Early Christian Fathers (New York: The MacMillan Company, 1970), p. 260.

$130 \mathrm{Jolmn}$ Chrysostom, Commentary on Galatians, V, 12. trans. by Rev. Gross Alexander, as found in vol. is of The Nicene and Post-Nicene Eathers, edited by Philip Schaff (New York: Charles Scribner's Sons, 1889), p. 39.

151 For example, there is the case of a sister, on the point of death, refusing to see her brother because of the danger of temptation (The sayings of the 
Fathers, Part IV, 61, as found in Western Asceticism. p. 58). Another instance concerns the hermit who wrapped his hands with a cloak before carrying his old mother across a river lest he remember the fire of a woman's body (The Sayings of the Eathers, Part IV, 68, as found in Western Asceticism, p. 59).

${ }^{152}$ Pourrat, p. 114 .

$153 \mathrm{Jerome}$, Letter to Eustochium 22, 7, 2, trans. by Charles Christopher Lawler, as found in vol. 33 of Ancient Christian Writers (Westminster: The Newman Press, 1963), p. 140 .

"s"For example, Jerome writes: "As long as we are imprisoned within this frail little body, as long as we have this treasure in earthen vessels, and the spirit Iusteth against the flesh and the flesh against the spirit, there is no sure victory." [Letter to Eustochium 22, 4, vol. 33 of Ancient Christian Writers, p. 163]. In line with the above, bodily comfort was considered to be taboo: Abba Poemen said: "If a monk will hate two things, he can be free of this world." And a brother said: "What are they?" And the old man said: "Bodily comfort and vain glory." The Sayings of the Fathers, I, 14, as found in Western Asceticism, p. 39 .

1350wen Chadwick, John Cassian: A study in Primitive Monasticism, p. 71 .

iscorigen is said to have written: "Ego autem licit non usque quaque pronuntiem, puto tamen quod sint in nonnullis etiam communibus hominem gestis, quae, quamis peccato careant, non tamen digna videantur, quibus interesse putemus Spiritum sanctum. Ut verbi gratia dixerim, conubia legitima careant quidem peccato nec tamen tempore illo, quo coniugales actus geruntur, praesentia sancti spiritus dabitur, etiamsi propheta esse videatur, qui officio generationis obsequitur. Sed et alia plura sunt, in quibus sola sibi sufficit vis humana et neque decet adesse praesentiam spiritus sancti . . " Origenes, Homilia VI, 4, as found in Die Griechischen Schrift-steller der Ersten Drei Jahrhunderte, vol. 30 (Leipsic: J. C. Hinrich's sche Buchhandlung, 1921), p. 35 .

is 'Pourrat, p. 305.

13 Ibid. , p. 114 .

139 The following casts light upon the point in question: "They told a story of an old man who was dying in scete. The brothers stood around his bed, and clothed him, and began to weep. But he opened his eyes 
and began to laugh; it happened three times. So the brothers asked him: "Tell us, Abba, why do you laugh at our weeping?" And he told them: "I laughed the first time because you fear death; I laughed the second time because you are not ready for death; I laughed the third time because I am passing from labor to rest, and yet you weep." And so saying, he closed his eyes and died." The sayings of the Fathers, $X I, 52$, as found in Western Asceticism, p. 140 .

's'See for example, Rudolf Bultmann, Theology of the New Testament, trans. by kendrick Grobei, I (New York: Charles Scribner's Sons, 1955), pp. 3-26; Günther Bornkamn, Jesus of Nazareth, trans. by Irene and Fraser McLuskey wi th James M. Robinson (New York: Harper \& Row, 1960), pp. 64-143; Norman Perrin. Rediscovering the Teaching of Jesus (New York: Harper \& Row, 1976), pp. 54-108; Hans Conzelmann, Jesus. trans. by J. Raymond Lord (Philadelphia: Eortress Press, 1973), pp. 54-71; Joachim Jeremias, The Parables of Jesus, trans. by S. H. Hooke (New York: Charles Scribner's Sous, 1972), p. $115 \mathrm{f}$.

'G'Hans Conzelmann, Jesus, p. 60.

162 Günther Bornkamm, Jesus of Nazareth, p. 108.

${ }^{163}$ Rudolf Schnackenburg, The Moral Teaching of the New Testament, trans. by J. holl and-Smith and $\frac{\text { W. }}{\mathrm{W}}$. o'Hara (New York: The Seabury Press, 1965), p. 100.

16"Ethelbert Stauffer, "Agape," Gerhard Kittel, ed., Theological Dictionary of the New Testament. trans. by Geoffrey W. Bromiley. I (Grand Rapids: Wm. B. Eerdmanns Publishing Company, 1964), p. 45.

16'The Sayings of the Eathers: XI, 35; XV, 32; XV, 47. as found in Western Asceticism, pp. 137, 165, and 167.

'ccassian's Conference \#10 (as edited by Owen Chadwick in Western Asceticism, pp. 233-246) stresses that a monk should pray from the moment he awakes in the morning until the instant he falls asleep at night.

"'Benedict stresses the the Lord should be loved with". . . all the heart, with all the soul, and with all the strength"; that one should renounce oneself in order to follow Christ; and that one should prefer nothing before the love of Clirist. See The Rule of Saint Benedict as found in Western Asceticism, p. 297.

"'In his introductory remarks to Western Asceticism. Owen Chadwick writes: "The Rule did not quickly win acceptance. Monks under the influence of 
traditional Egyptian thought probably believed it to be lukewarm because it demanded so little physical mortification." (Western Asceticism, p. 28).

"Hans Küng, On Being a Christian, trans. by Edward Quinn (Garden Ci t.y: Doubleday \& Company, Inc.. 1976), p. 198.

${ }^{10 \mathrm{~K}}$. G. Kuhn, "Askese, IV. Im Urchristentum," Die Religion in Geschichte und Gegenwart: Handwörterbuch für Theologie und Religionswissenschaft (Tubingen, 1957). II. 643 .

${ }^{172}$ Bornkamm, p. 148.

172 Schnackenburg, p. 148 .

${ }^{13}$ Perrin, p. 160.

27"Eduard Schweizer, The Good News According to Matthew, trans. by David E. Green (Atlanta: John Knox Press, 1975), pp. 383-384.

${ }^{173}$ Hans Conzelmann, An Outline of the Theology of the New Testament, trans. by John Bowden (New York: Harper \& Row, 1969), p. 90. For an excellent treatment of Paul's attitude toward marriage see: D. E. H. Whitely, The Theology of st. Paul (Oxford: Basil Blackweil, 1974), Pp. 215-216.

1"Louis Bouyer, Introduction to Spirituality, trans. by Mary Perkins Ryan (Collegeville: Liturgical Press, 1961), p. 133.

177 . . . fasting, watching, meditation on Scripture, nakedness and poverty are not perfection but the means toward it; not the end of our discipline, but the means toward that end. The man who is content with these practices as the summum bonum and not as means, will use them in vain. He possesses the tools of the trade but has no idea what they are used for." (Joln Cassian, Conferences, I, 7, as found in Western Asceticism, p. 199).

irReferring to the many ways of contemplating God, Abba Moses is quoted by Cassian as having said: "." - we know him in the majesty of his creation, in regarding his justice, in apprehending the help we receive in our daily lives. We contemplate him.. when we feel awe at the mighty power which rules creation . . . When we remember that he has counted the grains of sand upon the shore and the waves upon the sea and the raindrops, that he sees every day and hour through all the centuries past and future.. . "John 
Cassian, Conferences, I, 15, as found in Western Asceticism, p. 206 .

17'Jerome writes to Heliodorus: "Lo, the adversary within your very breast is attempting to kill Christ. Lo, the camp of the enemy pants for the donative which you received when about to set forth on military service. Even if your little nephew is clinging to your neck, although your mother with disheveled hair and torn garments is displaying the breasts with which she nurtured you, although your father lies on the threshold, trample your father and set forth. Fly with dry eyes to the standard of the cross. Cruelty is a kind of dutiful conduct in these circumstances." Jerome, Letter 14, trans. by Charles Christopher Mierow, Ph.d., as found in vol. 33 of Ancient Christian Writers (New York: Newman Press, 1963), p. 60 .

$10{ }^{\circ}$ Conzelmann. An Outline of the Theology of the New Testainent, p. 20 .

"'Werner Georg Kümmel, The Theology of the New Testament, trans. by John E. Steely (Nashville: Abingdon Press, 1973), pp. 174-177.

1"20nzelmann, An Outline of the Theology of the New Testament. p. $17 \overline{3}$.

1'I renaeus, Adversus Haereses, $1,28,1$, as found in vol. 1 of The Ante-Nicene Fathers, edited by Rev. Alexander Roberts and James Donaldson (New York: Charles Scribner's Sons, 1905), p. 353 .

1" John Chrysostom, Commentary on Galatians, V, 12, vol. 13 of The Nicene and Post-Nicene Eathers, p. 39.

1"5enzinger-Schönmetzer, Enchiridion Symbolorum Definitionum et Declarationun, editio XXXVI (Roma, MCMLXXVI), p. 158 .

"Conzelmann, An Outline of the Theology of the

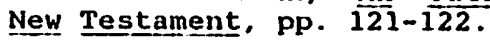

1.'E. Schillebeeckx, "Explicit Motivation for Clerical Celibacy in the History of the Church," as found in George $H$. Frein, Celibacy: the Necessary Option (New York: Herder and Herder, 1968), p. 53.

"John Cassian, Conferences, 19, 9, as found in Western Asceticism, p. 284 . 